\title{
TEMPORAL DYNAMICS OF DEEP INFRALITTORAL MACROBENTHIC FAUNA INSIDE A SUBTROPICAL ESTUARINE ENVIRONMENT
}

\author{
Pinotti, R. M. ${ }^{1 *}$; Colling, L. A. ${ }^{1} \&$ Bemvenuti, C. E. \\ Laboratório de Ecologia de Invertebrados Bentônicos, Instituto de Oceanografia, Universidade \\ Federal do Rio Grande - FURG, Rio Grande, RS, Brazil. \\ 1 - Programa de Pós-graduação em Oceanografia Biológica \\ * Contacting author: raphael.oceano@gmail.com
}

\begin{abstract}
Pinotti, R. M.; Colling, L. A. \& Benvenutti, C. E. 2011. Temporal dynamics of deep infralittoral macrobenthic fauna inside a subtropical estuarine environment. Braz. J. Aquat. Sci. Technol. 15(1): 26-41. ISSN 19839057. Seasonal and inter-annual patterns of hydrological variation determine different salinity regimes inside the Patos Lagoon estuarine region, southern Brazil. Throughout two environmentally distinct years (2000 and 2006), macrobenthic samples were taken seasonally from a $14 \mathrm{~m}$ deep main channel region, at nine monitoring sites, using a van Veen grab $\left(0.078 \mathrm{~m}^{2}\right)$. In order to keep the Patos Lagoon main access channel at constant navigable depths, the Rio Grande Harbour Superintendence periodically executes maintenance dredging operations on this infralittoral area, but our multivariate analyses evidenced no significant difference between dredged and non-dredged sites regardless the year. Among the abiotic parameters analyzed here (temperature, percentage of fine sediments and salinity), the later was evidenced to be highly correlated to the biological data. Reductions in density and/or changes in the species composition could both be attributed to a natural macrobenthic response related to environmental variations. Along the year 2000 high salinity values decreased constantly through seasons to almost limnetic condition in spring, reducing diversity and abundance of marine species and densities of the dominant gastropod species Heleobia australis. On the other hand, salinity values along the year 2006 revealed the maintenance of brackish waters throughout seasons, favoring the input and survival of marine species from coastal adjacent areas inside the estuary, raising its macrobenthic diversity mainly by mollusks and polychaete worms.
\end{abstract}

Keywords: Salinity, diversity, dredging, estuary, Patos Lagoon

\section{INTRODUCTION}

Despite the several definitions reviewed by Elliot \& McLusky (2002), estuaries are found to be habitats that present high variability and low predictability degree on the environmental variables, characterizing them as naturally stressed systems (Elliot \& Quintino, 2007). Inside estuarine regions, sediment characteristics of the substrate (e.g. grain size, organic matter content) and in particular salinity of the water column have long been reported as the main abiotic variables which can determine the spatial-temporal patterns of distribution on macrobenthic assemblages (Holland et al., 1987; Warwick et al., 1991; Schlacher \& Wooldridge, 1996; Mannino \& Montagna, 1997; Giménez et al., 2005; Cortelezzi et al., 2007).

Given the intense dynamic physical nature of estuaries and the physiological limits of each species, the estuarine macrobenthic fauna is found to be directly influenced by salinity due to its low mobility (McLusky \& Elliot, 2004), but rather than absolute tolerance, the major factor influencing the distribution of species in estuaries is the salinity variation (Attrill, 2002). For instance, spatial salinity gradient and its temporal variability are inherent features of estuarine systems that are able to affect both density and composition of macrobenthic species on subtropical coastal lagoons (Bemvenuti et al., 1992; Bemvenuti \& Netto, 1998).

The Brazilian south coast can be characterized by the presence of estuaries and coastal lagoons like the Patos Lagoon, a subtropical environment (Seeliger \& Kjerfve, 2001). Within this area and towards the south there are found an estuarine region that connects the lagoonal area to the Atlantic Ocean (Asmus, 1997) and also the Rio Grande Harbour, one of the most important Brazilian and South American port which traded in 2009 more than 23 million tons in commodities and 627 thousands TEU containers (http://www.portoriogrande. com.br).

High levels of pluviometric precipitation and the coupled fluvial discharge processes in the Patos Lagoon drainage basin are both responsible for the extensive transport of silt and clay sediments into the estuarine region, where in its channel areas the suspended matter may experience depositional processes (Calliari et al., 2009). Channel areas like these rarely have a constant navigable depth since large volumes of fine sediments deposit in their deeper parts, and subsequently their depth have to be artificially kept through periodic dredging to ensure accessibility to harbour and fish terminals, 
structures that are vital to the economic development of coastal regions (Engler et al., 1991).

The input of freshwater from the Patos Lagoon drainage basin system is also configured as one of the major sources of salinity variation inside this estuarine region as well as the action of predominant winds (Costa el at., 1988). Besides its seasonal structure, expressive inter-annual variations in the salinity patterns can also be found (Möller, 1996), characterizing years of low estuarine salinity and/or limnetic conditions like the year 2000 (Bemvenuti et al., 2005) in contrast to those years like 2006, in which brackish waters prevail (Capítoli et al., 2007).

Since the macrobenthic fauna in coastal lagoons may present unpredictable seasonal and inter-annual fluctuations related to the environment (Barnes, 1980), the present work aimed to analyze the temporal variability of the infralittoral macrobenthic assemblages on environmentally distinct years (2000 vs. 2006) and evaluate whether inter-annual differences eventually registered in the macrobenthic density and diversity can both be associated to the salinity fluctuations observed within the estuarine region of this subtropical lagoon.

\section{MATERIAL AND METHODS}

\section{Study Area}

At the coastal plain of the southern Brazil (Rio Grande do Sul state), the Patos Lagoon stretches in a NE-SW direction from 30 $30^{\prime} \mathrm{S}$ to $32^{\circ} 12^{\prime} \mathrm{S}$, near the city of Rio Grande. This subtropical coastal lagoon is classified as the world's largest choked lagoon (sensu Kjerfve, 1986), comprising shallow embayments and deep channels within a total area of $10227 \mathrm{~km}^{2}$. Inside this extensive lagoonal area, an estuarine region of 971 $\mathrm{km}^{2}$ is found southwards (sensu Closs, 1962) exchanging estuarine waters with the Atlantic Ocean through a $700 \mathrm{~m}$ wide artificial inlet. The Patos Lagoon main tributary rivers and their affluents drain a continental area of $201626 \mathrm{~km}^{2}$ forming the Patos-Mirim drainage basin system, in which high pluviometric precipitation and complex patterns of fluvial discharge result in elevated dynamic on both hydrographic and sedimentary processes (Asmus, 1997).

Deep infralittoral areas inside the estuarine region are represented by natural and artificially dredged channels with average depths of $10 \mathrm{~m}$ in which silty clay bottoms are found, but sandy and/or biodetritic bottoms can occur in those grounds with high hydrodynamic energy near the mouth of the lagoon (Capítoli et al., 1978; Calliari, 1997). The average amount of suspended matter inside the lagoon can vary between 43 and $196 \mathrm{mg} \mathrm{l}^{-1}$, which gives for the Patos Lagoon an estimated long-term sedimentation rate at $0.75 \mathrm{~mm} \mathrm{yr}^{-1}$ and a short-term sedimentation rate between 3.5 and $8.3 \mathrm{~mm} \mathrm{yr}^{-1}$ (Calliari et al., 2009).

The main navigation channel of the estuarine region is daily used as navigation routes for several cargo tank and container ships due to the Rio Grande Harbour operations. Besides economically important, this international trade activity potentially adds a maninduced factor which may control the estuarine macrobenthic fauna, either through chemical accidents (Bemvenuti et al., 2003) or dredging (Bemvenuti et al., 2005). In the last 20 years, an annual average of $1.510^{6} \mathrm{~m}^{3}$ of silty sand sediments have been dredged from the Rio Grande Harbour area, although large quantities of finer sediments are also dredged, like clayey silt and silty clay sediments (Calliari et al., 2009).

The rivers Jacuí (mean annual discharge of 801 $\left.\mathrm{m}^{3} \mathrm{~s}^{-1}\right)$, Taquari $\left(452 \mathrm{~m}^{3} \mathrm{~s}^{-1}\right)$ and Camaquã $\left(307 \mathrm{~m}^{3} \mathrm{~s}^{-1}\right)$ are the most important fluvial sources of water on the Patos system, besides the São Gonçalo channel (660 $\mathrm{m}^{3} \mathrm{~s}^{-1}$ ) which drains freshwater from the Lagoa Mirim system (Hartmann \& Harkot, 1990; Vaz et al., 2006). Showing a discharge pattern reliable to those on temperate regions, these tributary rivers usually present elevated water discharge on later winter and earlier spring followed by low to moderate flows through summer and autumn seasons (Möller, 1996). Significant rainfall variations in its drainage basin may also occur due to the influence of global-scale events like the El Niño Southern Oscillation (ENSO) in the southern Brazil, where wet and drought periods influence the Patos Lagoon estuarine region under El Niño and La Niña events, respectively (Grimm et al., 1998).

Located within a region of minimal tidal influence, tides in the Patos Lagoon are predominantly mixeddiurnal with mean tidal amplitude of $0.47 \mathrm{~m}$ (Garcia, 1997). Since most choked coastal lagoons are wind forced rather than tidal driven, another source of salinity variation inside this estuarine region in addition to the pluviometric and fluvial induced processes, comes seasonally from the frequency, intensity and direction of the regional NE-SW wind regime. Winds from the NE quarter predominate from the spring to summer (mean velocity between 3.6 and $5.1 \mathrm{~m} \mathrm{~s}^{-1}$ ) while winds from the SW quarter predominate from autumn to winter with mean velocities between 5.7 and $8.2 \mathrm{~m} \mathrm{~s}^{-1}$ (Garcia, 1997; Krusche et al., 2003). For instance, freshwater or oceaninfluenced situations in the estuarine salinity can be found due to elevated fluvial discharge associated to NE winds, and low freshwater runoff combined to strong S winds, respectively (Niencheski \& Baumgarten, 1997).

\section{Sampling and Statistical Analyses}

Samples were seasonally taken inside the Patos Lagoon southern estuarine region during the years 2000 and 2006, at nine monitoring sites distributed along 


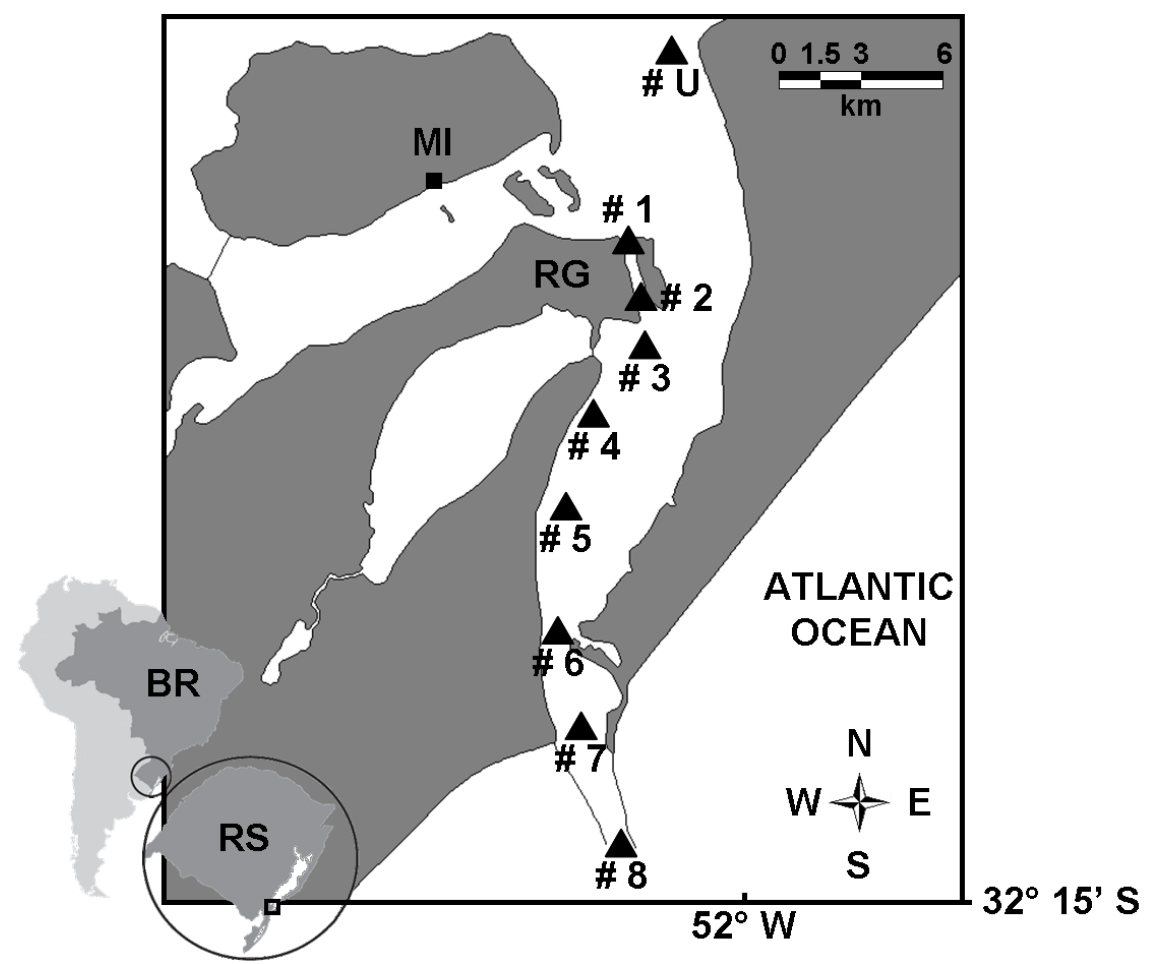

Figure 1 - Study area within the Patos Lagoon southern estuarine region illustrating the sampling scheme along the $14 \mathrm{~m}$ deep main channel area, from upstream the Rio Grande Harbour (\# U) to the jetties located at the mouth of Patos Lagoon (\# 8). Rio Grande city (RG) and Marinheiros Island (MI) are also represented.

the $14 \mathrm{~m}$ deep and $15 \mathrm{~km}$ long main channel (Fig. 1): one site located around $4.5 \mathrm{~km}$ upstream the Rio Grande Harbour area (\# $U$ ) and another eight sites spread from the upper Harbour (\# 1) to the jetties, located at the mouth of Patos Lagoon (\# 8).

In each monitoring site three biological samples were collected using a van Veen grab $\left(0.078 \mathrm{~m}^{2}\right)$, which there were sieved through a nylon sieve $(0.5 \mathrm{~mm}$ mesh size) and then preserved in a $4 \%$ formaldehyde solution. In the laboratory, macrobenthic fauna was sorted, identified and quantified under a stereoscopic microscope and then preserved in a $70 \%$ ethanol solution.

The mean total macrobenthic fauna densities as well as the dominant species densities were both expressed as $10^{3}$ individuals $\mathrm{m}^{-2}$. The number of species and its total number (as the sum of all species registered in the samples from a given area) were used together with indexes that also consider the relative species abundance in the community like H' (Shannon-Wiener) and J' (Pielou's evenness) as a measure of diversity (Stirling \& Wilsey, 2001).

Throughout this paper, the classification of species into estuarine or marine groups followed several studies on estuarine (Capítoli et al., 1978; Bemvenuti et al., 1992; Bemvenuti, 1997a,b; Bemvenuti \& Netto, 1998) and marine benthic macrofauna (Capítoli, 1997; Gianuca, 1997; Capítoli \& Bemvenuti, 2004).
Approximately $50 \mathrm{~g}$ of sediment were collected in each one of the nine sites at the time of benthic sampling for granulometric analyses by sieve and pipette techniques described in Suguio (1973), from which there were determined the fractions of sand, silt and clay.

Water temperature (thermometer with precision of $0.1^{\circ} \mathrm{C}$ ) and salinity (portable optic refratometer with precision of one unit) were both measured in situ at the time of sampling, being this later variable also daily taken from the PELD databank (PELD - Programas Ecológicos de Longa Duração - Site 8 - FURG; http:// www.peld.furg.br), a Brazilian long-term ecological program conduced in a shallow area near the southern margin of the Marinheiros Island (Fig. 1). These later salinity values were used throughout this work to calculate the trends of estuarine salinity and in the statistical analyses since long-term averages of environmental variables are considered more reliable than those obtained during sampling (Ysebaert \& Herman, 2002).

Spatial analyses on the granulometric fractions were tested by Kruskal-Wallis non-parametric analyses of variance $(p<0.05)$ and Dunn's post hoc tests whenever significant (Zar, 1984) since data did not attain the prerequisites of an ANOVA test. Given the predominance of fine granulometric fractions in the substrate of the studied channel (Calliari, 1997), only the percentages of fine sediments ( $\%$ silt $+\%$ clay) were used in the temporal analyses. 
Environmental (\% of fine sediments, temperature and salinity) as well as biological data (mean macrobenthic density and number of species) were transformed to attain their normality and homogeneity. These data were temporally tested involving seasonal (differences among the seasons within 2000 and within 2006) and inter-annual approaches (differences between the studied years: 2000 vs. 2006), both executed by One-way ANOVA $(p<0.05)$ and Tukey HSD post hoc tests whenever significant differences were found (Zar, 1984). Furthermore, Two-way ANOVA analyses ( $p<$ 0.05 ) were also applied to those biological data involving the comparisons between 2000 vs. 2006 pairwised seasons (summer/00 vs. summer/06; autumn/00 vs. autumn/06; and then successively), being executed Tukey HSD post hoc tests whenever significant.

In order to determine possible significant correlations between biological and environmental data, the Pearson product moment correlation coefficient (Zar, 1984) was used to compare the mean macrobenthic density, number of species, Shannon-Wiener's diversity index $\left(\mathrm{H}^{\prime}\right)$ and Pielou's evenness index ( $\mathrm{J}$ ') to such abiotic data: water temperature, percentage of fine sediments and salinity.

The Patos Lagoon main channel area is no longer a pristine environment, in which the Rio Grande Harbor Superintendence (SUPRG) periodically executes maintenance dredging. In this sense, investigations on dredging operations were performed by multivariate analyses (Clarke \& Warwick, 2001). During the year 2000 , dredging operations removed $2330000 \mathrm{~m}^{3}$ of sediment along the winter (sites \# 1 to \# 3) and spring seasons (sites \# 4 to \# 8). In the year 2006 these operations removed $986993 \mathrm{~m}^{3}$ of sediment from sites \# 1 and \# 2 (winter) and from sites \# 1 to \# 4 along the spring (SUPRG, unpublished data). Therefore, hierarchical cluster analyses were executed based in a Bray-Curtis Similarity Index to investigate potential differences among sampling sites regarding these dredging activities (dredged vs. non-dredged sites) during the winter and spring seasons in both analyzed years.

Besides this possible human-induced effect, multivariate analyses were also executed through ANOSIM tests (Analysis of Similarity; $p<0.05$ ) in order to evaluate the temporal macrobenthic natural variation between the studied years and among their seasons, being also executed SIMPER tests (Similarity Percentage) to evidence the species responsible for the differences found whenever significant. Furthermore, a non-metric Multi-Dimensional Scaling analysis (nMDS) was executed based in a Bray-Curtis Similarity Index with $\log (x+1)$ transformed biological data to support the group formations. All multivariate analyses were conducted using PRIMER v6 software (Clarke \& Gorley, 2006).

Table 1 - Results of seasonal and inter-annual One-way ANOVA on the environmental data and results of One-way and Two-way ANOVA on the total density and number of species. Small italic bold letters denote post hoc results. SM: summer; AT: autumn; WT: winter; SP: spring; ${ }^{* \star *}$ : absence of post hoc test since $\mathrm{p}>0.05$.

\begin{tabular}{|c|c|c|c|c|c|c|}
\hline Variable & Factor & SS & Df & $\mathbf{F}$ & $\mathbf{p}$ & Tukey HSD \\
\hline \multicolumn{7}{|c|}{ Fine sediments (\%) } \\
\hline & Seasons 2000 & 1422.400 & 3 & 1.116 & 0.356 & $* * *$ \\
\hline & Seasons 2006 & 1266.300 & 3 & 0.347 & 0.791 & $* * *$ \\
\hline & Year & 0.001 & 1 & 0.796 & 0.375 & $\star * *$ \\
\hline \multicolumn{7}{|l|}{$\mathrm{T}\left({ }^{\circ} \mathrm{C}\right)$} \\
\hline & Seasons 2000 & 0.007 & 3 & 49.418 & 0.000 & $\mathrm{SM} \boldsymbol{a}>\mathrm{SP} a \boldsymbol{b}>\mathrm{AT} \boldsymbol{b}>\mathrm{WT} \boldsymbol{c}$ \\
\hline & Seasons 2006 & 600.310 & 3 & 389.390 & 0.000 & $\mathrm{SM} \boldsymbol{a}>\mathrm{SP} \boldsymbol{b}>\mathrm{AT} \boldsymbol{c}>\mathrm{WT} \boldsymbol{d}$ \\
\hline & Year & 16.060 & 1 & 0.829 & 0.365 & $* \star *$ \\
\hline \multicolumn{7}{|l|}{ Salinity } \\
\hline & Seasons 2000 & 44.892 & 3 & 173.815 & 0.000 & $\mathrm{SM} \boldsymbol{a}>\mathrm{AT} \boldsymbol{b}>\mathrm{WT} \boldsymbol{c}>\mathrm{SP} \boldsymbol{c}$ \\
\hline & Seasons 2006 & 6.106 & 3 & 41.705 & 0.000 & $\mathrm{SM} \boldsymbol{a}>\mathrm{AT} \boldsymbol{a}>\mathrm{SP} \boldsymbol{b}>\mathrm{WT} \boldsymbol{b}$ \\
\hline & Year & 7.710 & 1 & 55.176 & 0.000 & $2006>2000$ \\
\hline \multicolumn{7}{|l|}{ Total density } \\
\hline & Seasons 2000 & $4.2110^{9}$ & 3 & 2.608 & 0.068 & $* * *$ \\
\hline & Seasons 2006 & 1.284 & 3 & 1.007 & 0.402 & $\star * *$ \\
\hline & Year & 8.471 & 1 & 22.321 & 0.000 & $2000>2006$ \\
\hline & Year vs. Seasons & 77.717 & 3 & 3.068 & 0.034 & AT/00 > AT/06 and WT/00 > WT/06 \\
\hline \multicolumn{7}{|c|}{ Number of species } \\
\hline & Seasons 2000 & 576.972 & 3 & 24.443 & 0.000 & $\mathrm{SM} \boldsymbol{a}>\mathrm{AT} \boldsymbol{a}>\mathrm{WT} \boldsymbol{b}>\mathrm{SP} \boldsymbol{c}$ \\
\hline & Seasons 2006 & 113.861 & 3 & 1.813 & 0.164 & $* * *$ \\
\hline & Year & 0.889 & 1 & 0.038 & 0.884 & $* * *$ \\
\hline & Year vs. Seasons & 265.222 & 3 & 6.139 & 0.000 & $\mathrm{SP} / 06>\mathrm{SP} / 00$ \\
\hline
\end{tabular}




\section{RESULTS}

Spatial differences in the bottom granulometry were registered for the year 2000 and 2006 comprising the percentages of sand $(p=0.002$ and $p=0.000$, respectively), silt ( $p=0.000$ and $p=0.003$, respectively) and clay $(p=0.196$ for the year 2000 but $p=0.001$ for
2006). Given these results, silty clay bottoms were more frequently registered in the central portion of the sampling area (from sites \# 2 to \# 6) when compared to those coarse bottoms found northwards (\# $U$ and \# 1) and southwards, near the Patos Lagoon mouth (sites \# 7 and \# 8), specially in 2006 (Fig. 2). Temporal differences regarding only the fine sediments percentages (silt +

Year 2000
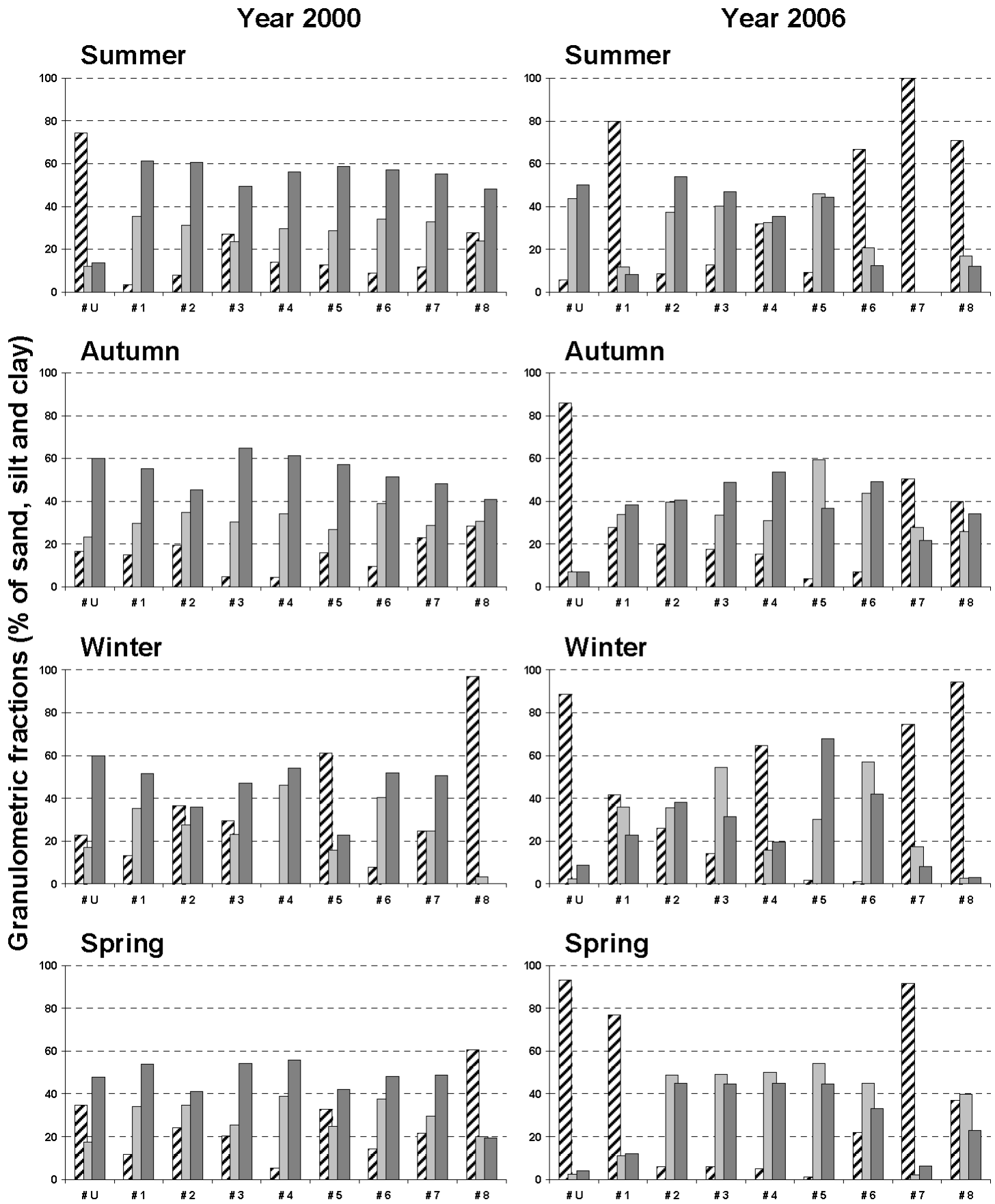

W/Asand

Silt

Clay

Figure 2 - Granulometric fractions of sand, silt and clay, seasonally registered in the substrate from the infralittoral estuarine region monitored sites (from sites \# U to \# 8) along the years 2000 (left) and 2006 (right). 
Table 2 - Macrobenthic fauna registered along sampling sites during summer (SM), autumn (AT), winter (WT) and spring (SP) seasons. (A): Amphipoda; (B): Bivalvia; (C): Cumacea; (D): Decapoda; (G): Gastropoda; (I): Isopoda; (T): Tanaidacea; (Ph): Phoronida; (*): Higher taxa containing one or more species.

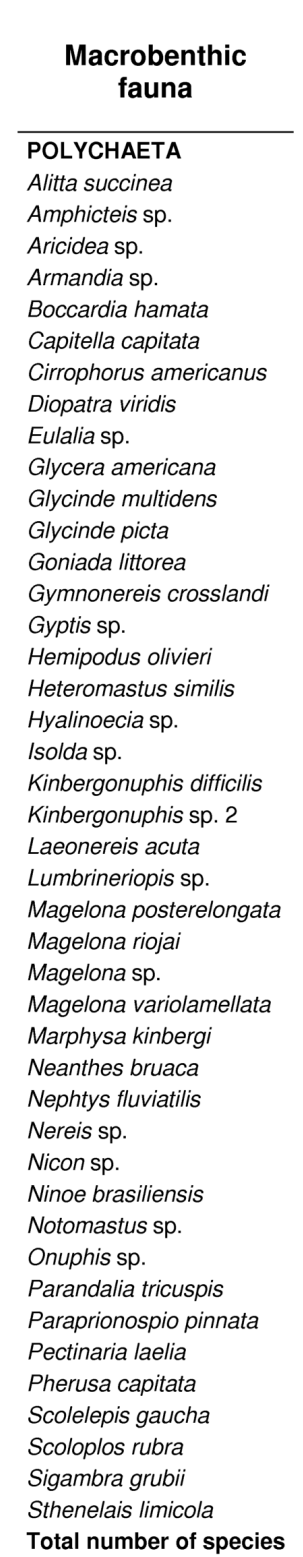

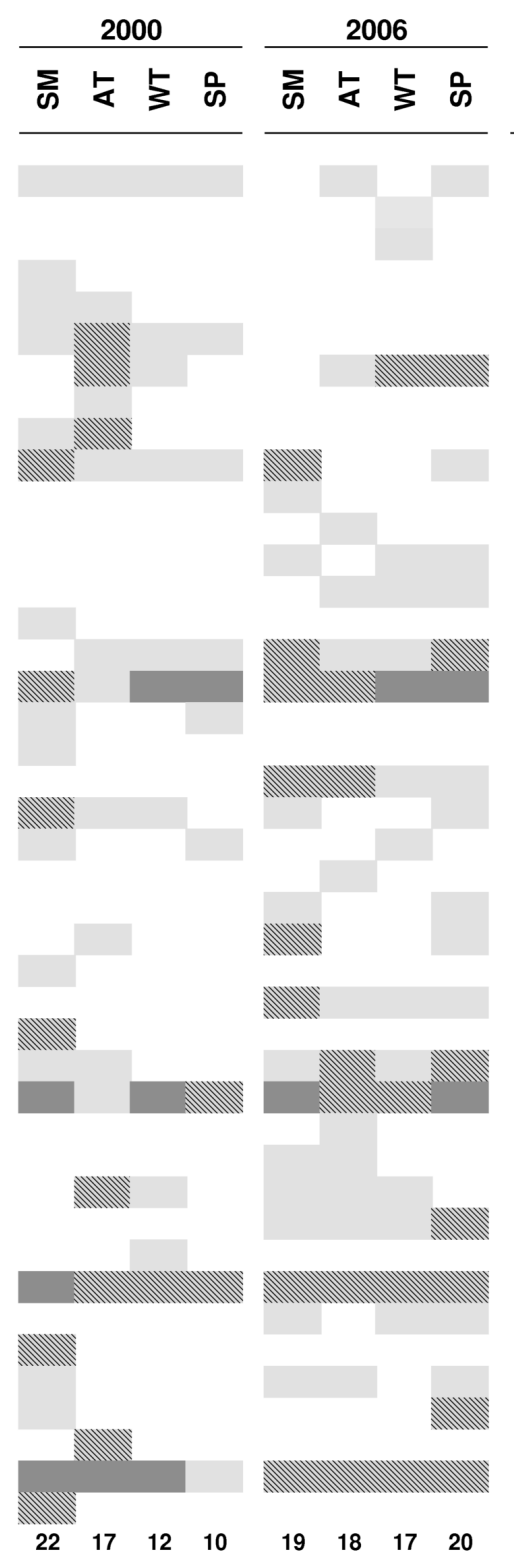

clay fractions) were not registered in both inter and intraannual approaches (Tab. 1).

Higher water temperatures were registered during summer/00 $\left(23.2^{\circ} \mathrm{C}\right)$ and summer/06 $\left(25.8^{\circ} \mathrm{C}\right)$ while lower ones were observed during winter/00 (12.2 $\left.{ }^{\circ} \mathrm{C}\right)$ and winter/06 $\left(15.0^{\circ} \mathrm{C}\right)$. The water temperatures along the autumn seasons were colder than those registered in the spring. There was not registered an inter-annual difference in the water temperature $(p=0.365)$ besides the significant intra-annual differences found for both years $(p<0.000$; Tab. 1$)$.

Salinity records registered inside the southern estuarine region evidenced a decreasing pattern in the salinity values along the year 2000 (Fig. 3a). Elevated

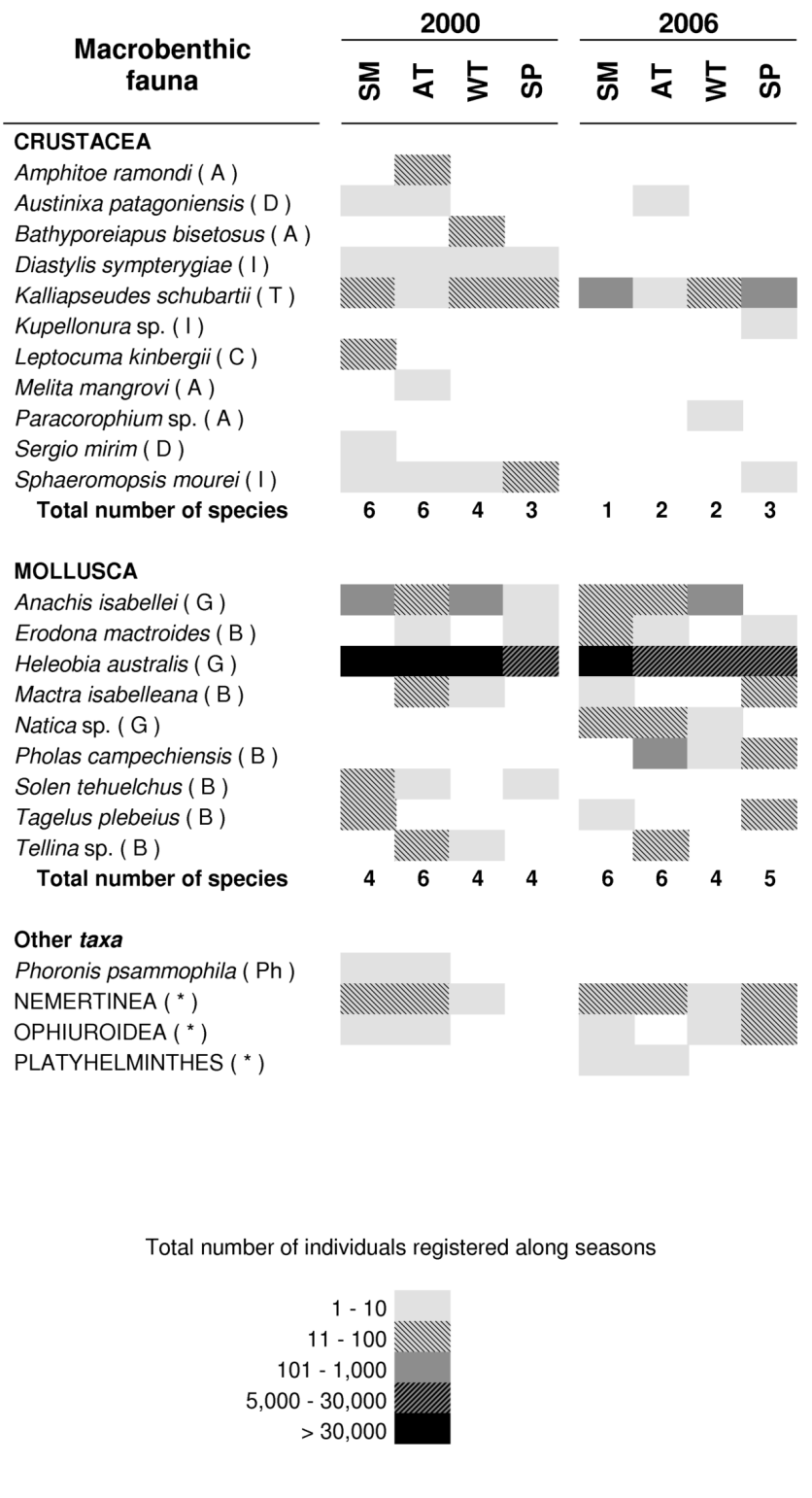

values of salinity were observed decreasing constantly through seasons, with consecutive reductions from summer to winter and then the maintenance of less salty waters along the spring season. On the other hand, salinity records along 2006 revealed the maintenance of brackish waters throughout the seasons, being registered just a salinity drop from autumn to winter (Fig. 3b). In addition to those significant intra-annual differences found within both years (Tab. 1), it was found that the year 2006 was significantly saltier than the year $2000(p<0.000)$.

Within the deep infralittoral area of this subtropical lagoon it was registered at least 67 macrobenthic species, in which the Polychaete class was found more 


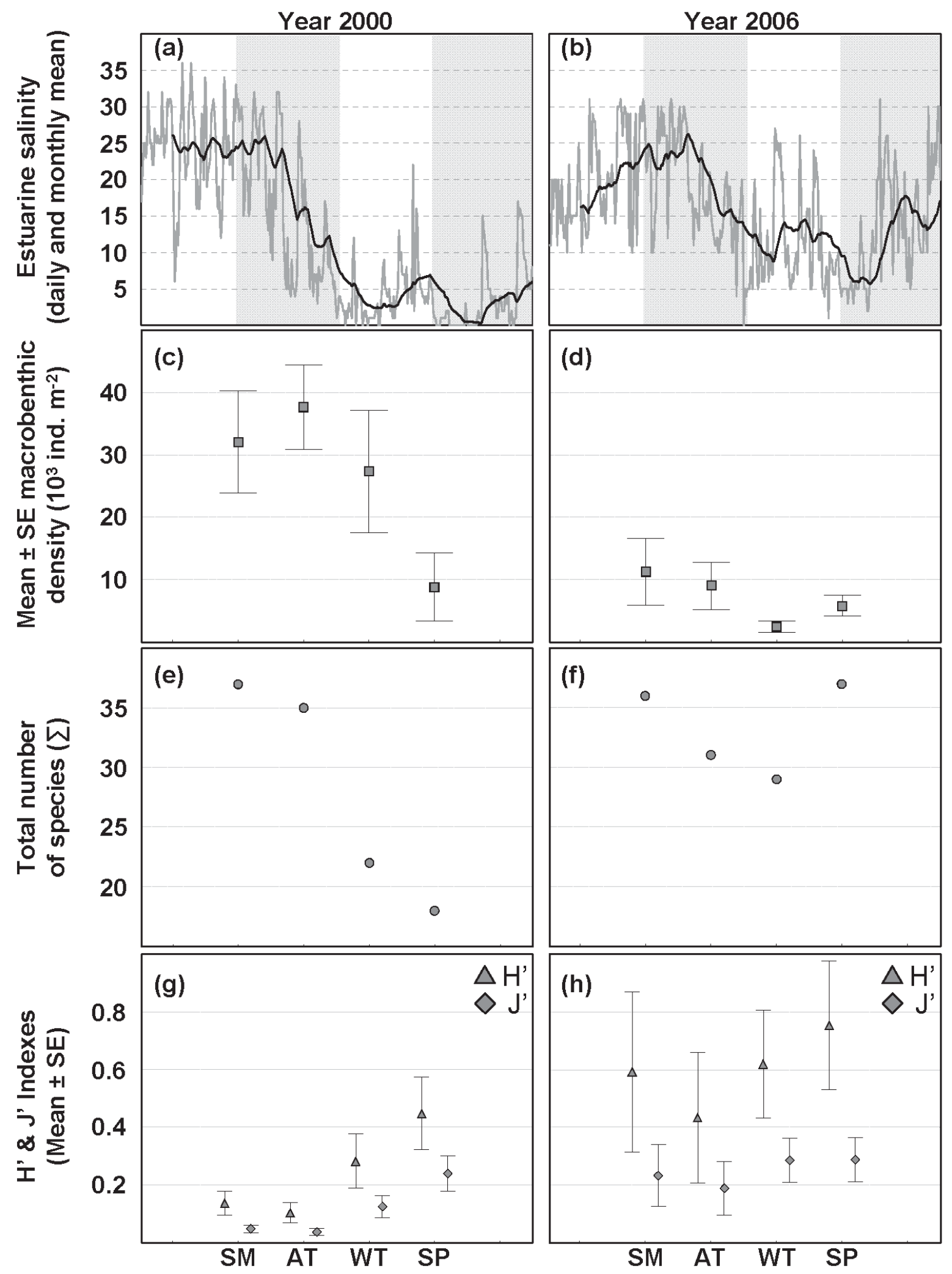

Figure 3 - Salinity values and macrobenthic fauna attributes registered along summer (SM), autumn (AT), winter (WT) and spring seasons (SP) in the years 2000 and 2006, respectively: (a / b) Estuarine salinity (daily values and monthly means); (c / d) Mean \pm SE of total macrobenthic density; (e / f) Sum of total number of species; (g/h) Shannon-Wiener's diversity (H') and Pielou's evenness (J') indexes. 
diverse (43 spp. comprising the whole study), followed by the subphylum Crustacea (11 spp.), the phylum Mollusca (9 spp.) and another four taxa including species of Phoronida, Nemertinea, Ophiuroidea and Platyhelminthes (Tab. 2). Despite of this Polychaete class' dominance in the macrobenthic diversity, an expressive dominance in terms of density was associated to the gastropod Heleobia australis d' Orbigny, 1835. Comprising the total macrobenthic density, this gastropod species was responsible for $98.90 \%$ of the total density in the year $2000(953,943$ ind. $\mathrm{m}^{-2}$ ) and for $92.53 \%$ of the total abundance in 2006
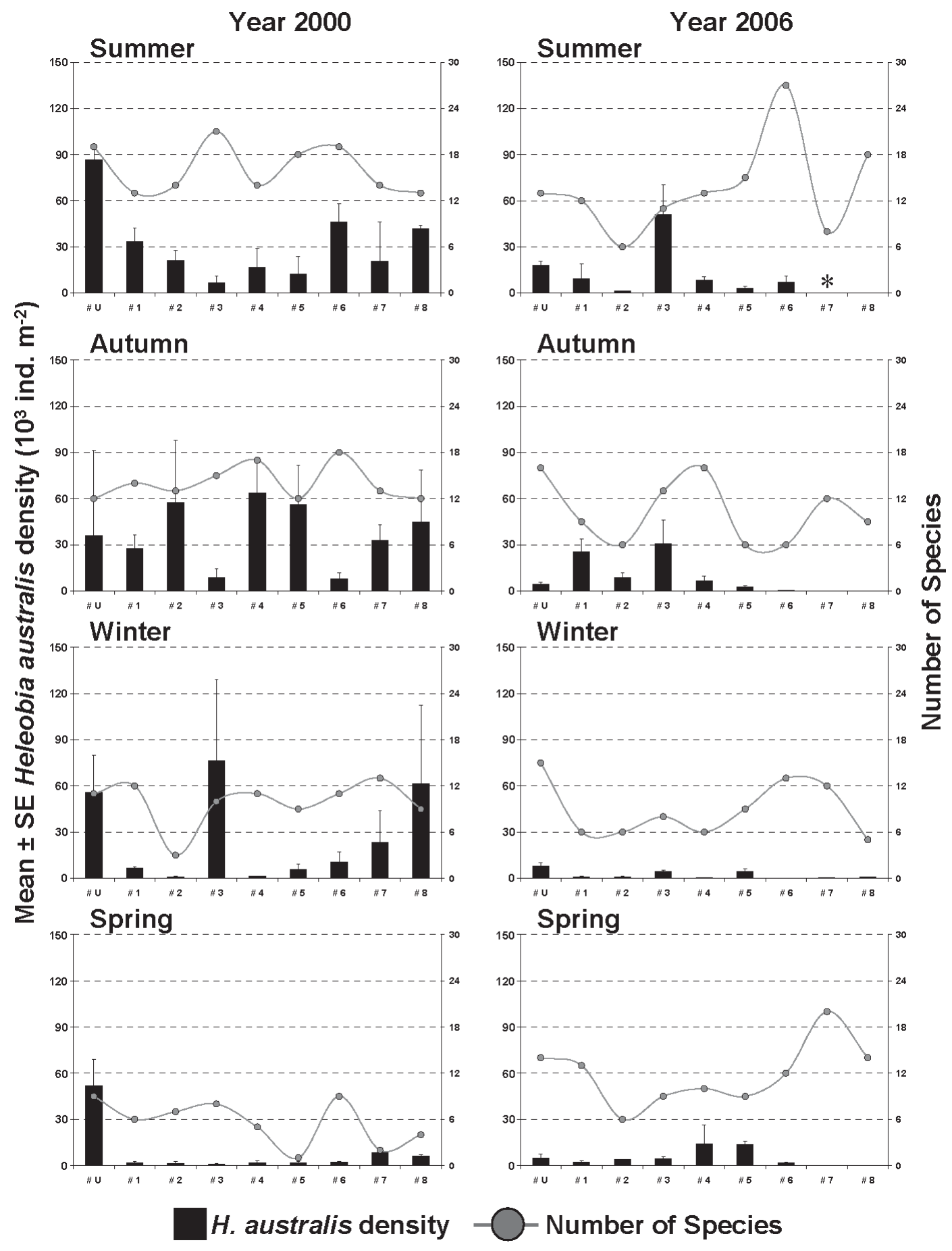

Number of Species

Figure 4 - Densities (mean \pm standard error) of the gastropod Heleobia australis (black bars) and number of species (grey dots), seasonally registered at the infralittoral estuarine region monitored sites (from sites \# U to \# 8) along the years 2000 (left) and 2006 (right). *: species absence. 
(255,778 ind $\left.\mathrm{m}^{-2}\right)$. This wide dominance also determined the lower values of abundance observed for other species such as the polychaete worms Heteromastus similis Southern, $1921(0.27 \%$ in the year 2000 and $2.29 \%$ in 2006), Sigambra grubii Müller, 1858 (0.25\% - 0.35\%), Nephtys fluviatilis Monro, $1939(0.10 \%-1.06 \%)$ and Parandalia tricuspis Müller, 1858 (0.09\% - 0.23\%); the gastropod Anachis isabellei Orbigny, 1841 (0.08\% $0.36 \%)$ and the tanaid Kalliapseudes schubartii MañéGarzón, 1949 (0.04\% - 0.52\%).

The mean macrobenthic densities along the seasons in the year 2000 were found higher than the respective seasons in the year 2006, determining significant inter-annual differences specially in the autumn and winter pairwised seasons (Tab. 1), besides the absence of significant intra-annual differences in the macrobenthic densities of both years (Fig. 3c,d). The total number of species registered throughout the seasons in the year 2000 revealed a significant intraannual pattern of decreasing diversity from summer to the spring (Fig. 3e; Tab. 1), a less marked and nonsignificant trend also found from summer to the winter 2006 (Fig. 3f; Tab. 1). There was not observed an interannual difference in the number of species between the analyzed years except for that related to the spring pairwised seasons (Tab. 1).

Benthic diversity and evenness were found lower along the seasons in 2000 than those in 2006 due to the increasing number of marine species and higher densities of the dominant gastropod $H$. australis, respectively. The great abundance of this species during summer/autumn and its reduction along winter/spring in 2000 were responsible for the lower values of evenness observed throughout this year as well as the decreasing salinity forced reductions in the marine species' densities, favoring only the estuarine ones (Fig. 3a,g). Otherwise, higher salinity and its low fluctuation throughout 2006, allied to the maintenance of the gastropod species' dominance in lower densities both favored the higher values of diversity and evenness found along 2006 (Fig. 3b,h).

When analyzed on a spatial approach (e.g. for each sampling site over time) it was possible to state an expressive spatial variation concerning the mean densities of the dominant $H$. australis and the number of species registered within this infralittoral estuarine area (Fig. 4). For instance, the maximum spatial variation in the species density was observed during the summer/ 00 , when densities were found ranging from 6,496 ind. $\mathrm{m}^{-2}$ (site \# 3) to 86,650 ind. $\mathrm{m}^{-2}$ (site \# U) as well as observed for the number of species, which were registered varying from $6 \mathrm{spp}$. (site \# 2) to $27 \mathrm{spp}$. (site \# 6) in the summer/06. This pattern of non-linear spatial variation in both density and diversity was responsible for distorting to the highest degree the statistical analyses under a spatial approach, evidencing a marked temporal rather than spatial source of variation comprising the estuarine and marine species within the Patos Lagoon estuary.

Correlating the environmental variables to the biological attributes, it was possible to state that the percentage of fine sediments was inversely correlated to the diversity and evenness biological indexes for both years, but especially for 2006, year in which the water temperature was directly correlated to the number of species (Tab. 3). Salinity values registered in the present study seems to play an important structuring factor to the macrobenthic fauna since it was strongly and directly

Table 3 - Results of correlation coefficient (Pearson) on environmental variables in relation to mean total density, number of species, Shannon-Wiener's diversity index ( $\left.\mathrm{H}^{\prime}\right)$ and Pielou's evenness index ( $\left.\mathrm{J}^{\prime}\right)$ in the years 2000 and 2006. Significant correlations are marked as: ${ }^{*}<0.05 ;{ }^{* *}<0.01 ;{ }^{* * *}<0.001$.

\begin{tabular}{|c|c|c|c|c|c|c|}
\hline \multirow{2}{*}{ Pair of variables } & \multicolumn{3}{|c|}{2000} & \multicolumn{3}{|c|}{2006} \\
\hline & Pearson $r$ & $r^{2}$ & $\mathbf{p}$ & Pearson $r$ & $r^{2}$ & $\mathbf{p}$ \\
\hline \multicolumn{7}{|l|}{ Fine sediments (FS) } \\
\hline (FS) vs. Total density & -0.199 & 0.039 & 0.250 & 0.303 & 0.091 & 0.072 \\
\hline (FS) vs. Number of spp. & 0.191 & 0.036 & 0.269 & -0.316 & 0.099 & 0.060 \\
\hline (FS) vs. H' & -0.391 & 0.152 & * & -0.530 & 0.281 & $* * *$ \\
\hline (FS) vs. J' & -0.327 & 0.107 & 0.054 & -0.509 & 0.259 & ** \\
\hline \multicolumn{7}{|l|}{ Temperature $(\mathrm{T})$} \\
\hline (T) vs. Total density & 0.168 & 0.028 & 0.334 & 0.283 & 0.080 & 0.093 \\
\hline (T) vs. Number of spp. & 0.301 & 0.091 & 0.077 & 0.393 & 0.154 & * \\
\hline (T) vs. $H^{\prime}$ & 0.029 & 0.000 & 0.867 & -0.037 & 0.001 & 0.827 \\
\hline (T) vs. J' & 0.068 & 0.004 & 0.697 & -0.098 & 0.009 & 0.569 \\
\hline \multicolumn{7}{|l|}{ Salinity (S) } \\
\hline (S) vs. Total density & 0.496 & 0.246 & $* *$ & 0.241 & 0.058 & 0.156 \\
\hline (S) vs. Number of spp. & 0.752 & 0.566 & $* \star *$ & 0.241 & 0.058 & 0.156 \\
\hline (S) vs. $H^{\prime}$ & 0.248 & 0.061 & 0.149 & -0.294 & 0.086 & 0.080 \\
\hline (S) vs. J' & 0.382 & 0.145 & * & -0.349 & 0.122 & * \\
\hline
\end{tabular}




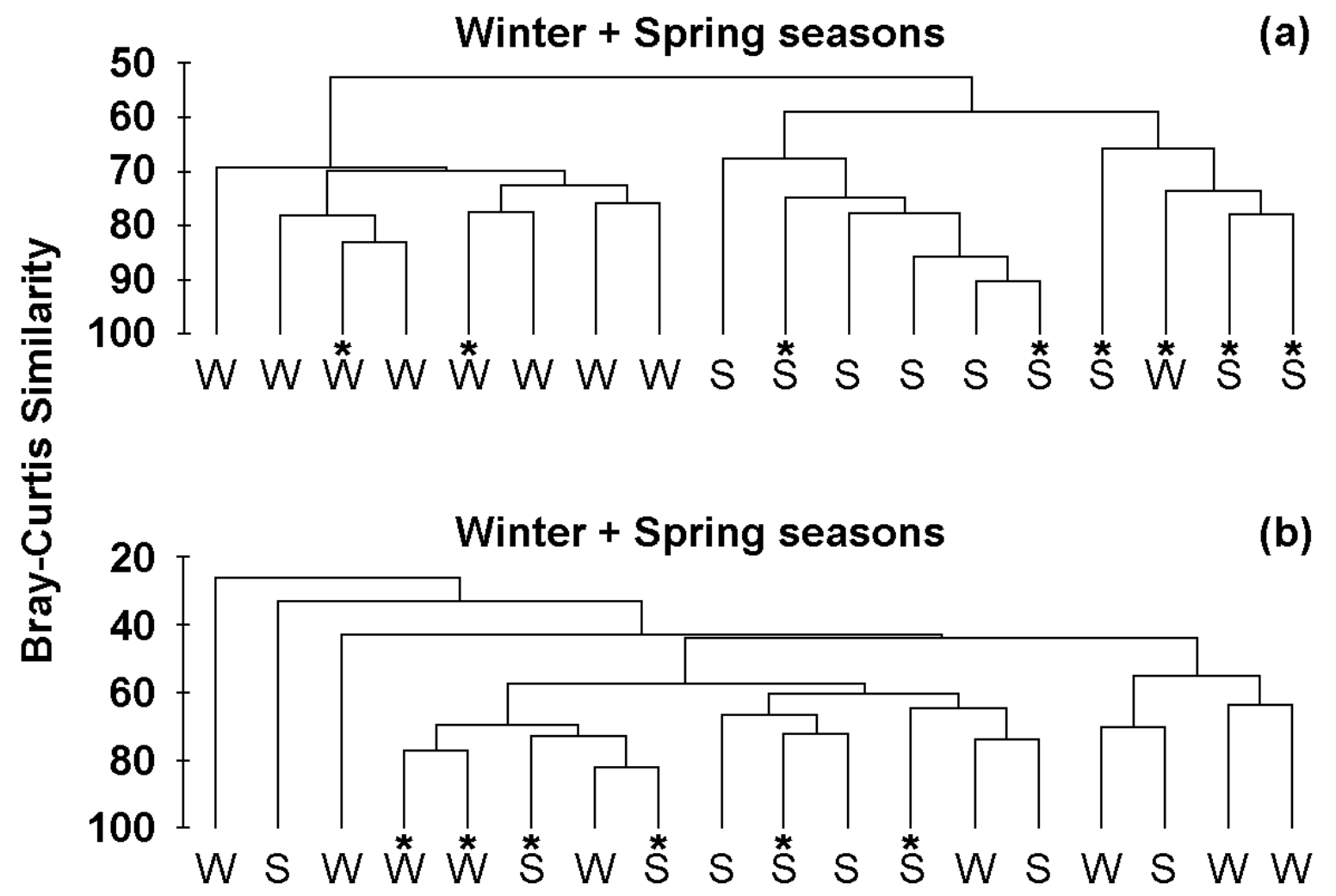

Figure 5 - Cluster analyses on dredged vs. non-dredged sites along the main channel area evidencing no differences regarding dredging activities during the winter (W) and spring seasons (S) for the years: (a) 2000 [ANOSIM; $p=0.123$ ]; and (b) 2006 [ANOSIM; $p=0.245$ ]. Dredged sites are marked $\left({ }^{*}\right)$.

correlated to the total macrobenthic density, to the number of species and to the evenness index in the year 2000 and was also inversely correlated to this later index in 2006 (Fig. 3a-h; Tab. 3).

Evaluating the possible effects of dredging upon the macrobenthic fauna, there were not found any significant difference between dredged and non-dredged sites, either in the winter/spring seasons for the year 2000 (ANOSIM; $p=0.123 ; R=0.097$; Fig. $5 a$ ) or in these seasons for 2006 (ANOSIM; $p=0.245 ; R=0.080$; Fig. 5b). It was stated that the macrobenthic fauna was seasonally rather than anthropicaly driven, especially in the segregation of seasons within the year 2000.

Results on multivariate analyses stated an interannual macrofaunal distinction in which the macrobenthic assemblages throughout the years 2000 and 2006 were found slightly but significantly apart (ANOSIM; $p=0.001$; $\mathrm{R}=0.165$; Fig. 6a), as well as observed for the salinity values, both inter and intra-annually (Tab. 1). It was also possible to evidence a marked intra-annual segregation for the year 2000 macrobenthic assemblages (Fig. 6b; Tab. 4) and a not so clear seasonal distinction within 2006 (Fig. 6c), in which the macrofaunal structure in the autumn/winter pairwised seasons were found quite similar (ANOSIM; $p=0.068 ; R=0.132 ;$ Tab. 4).

\section{DISCUSSION}

Changes in both hydrological and sedimentary characteristics generally are related to dredging operations (Blanchet et al., 2005; Dauvin et al., 2010) but in the present work no evidence of substrate changes was temporally evidenced. Fine sediments were commonly found in the central sampling area in contrast to those coarser sediments frequently found north and southwards, this later area recognized as poorly structured in relation to diversity and abundance of estuarine species due to hydrodynamic disturbances (Bemvenuti et al., 1992).

Differences on macrofaunal diversity and density impoverishment are findings commonly associated to periodic dredging (Marques et al., 1993; Quigley \& Hall, 1999; Skilleter et al., 2006), activities that may raise the mortality events and alter permanently the macrobenthic assemblages (Kennish, 1992). Our results on dredging operations, however, suggested no evidence of any effects upon the macrobenthic structure because density, composition and number of species between dredged and non-dredged sites were found similar.

Direct effects upon the macrobenthic fauna were observed during dredging operations in the Bayou Texar 


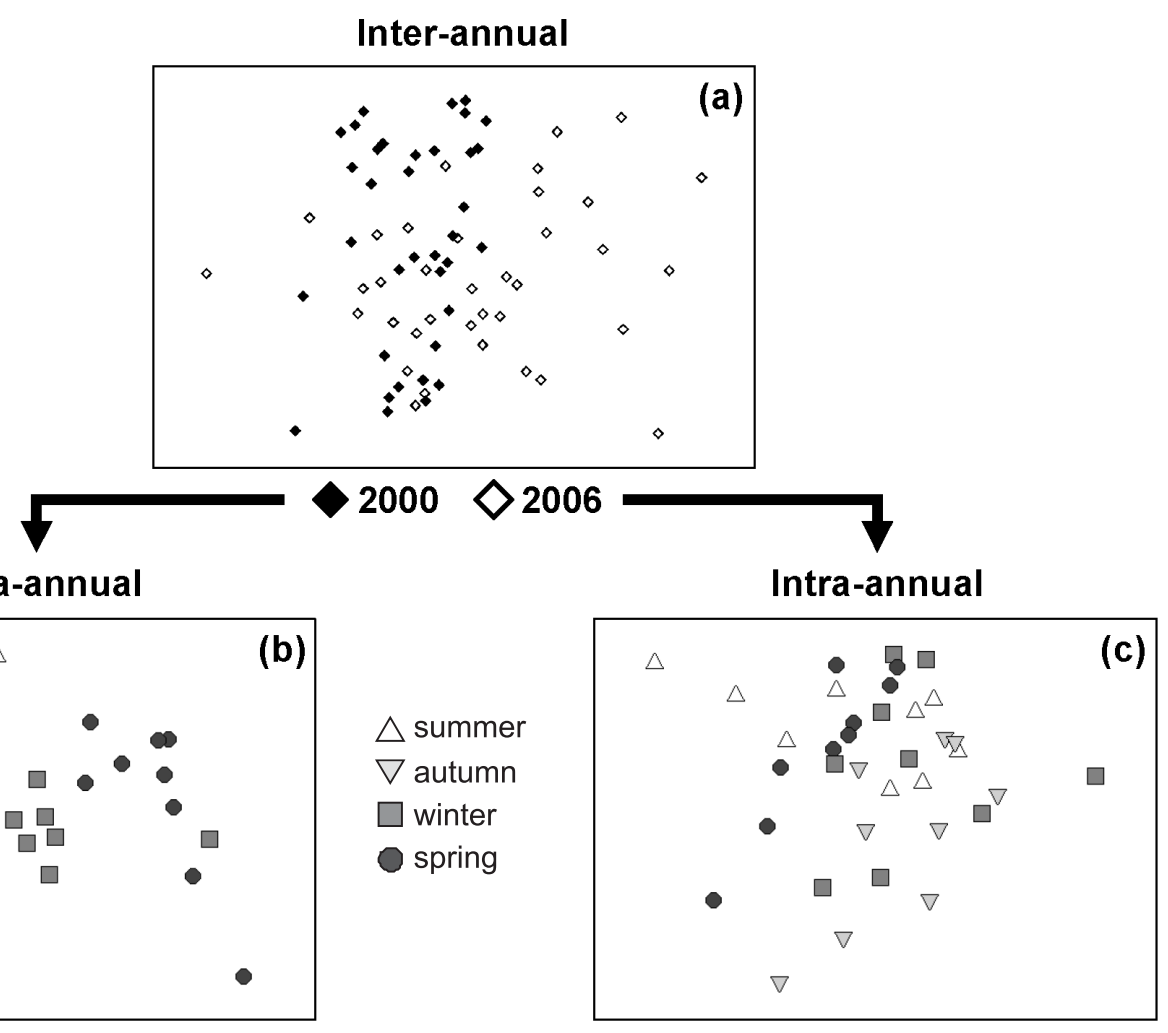

Figure 6 - nMDS results evidencing (a) inter-annual segregation of the macrobenthic infralittoral assemblages for the years 2000 and 2006 [ANOSIM; $p=0.001$ ]; (b) a marked distinction of seasons for the year 2000 [ANOSIM; global $p=0.001$ ]; and (c) a less evident, but significant, intra-annual structure for 2006 [ANOSIM; global $p=0.001$ ].

Table 4 - ANOSIM and SIMPER analyses results attesting the temporal segregation observed by the presence and/or abundance of marine and estuarine macrobenthic species throughout the years or seasons in which they occurred. ${ }^{*}:<0.05 ;{ }^{* *}:<0.01 ;{ }^{* * *}:<0.001$; ns: not significant; (0): 2000; (6): 2006; (SM): summer; (AT): autumn; (WT): winter; (SP): spring.

\begin{tabular}{|c|c|c|c|}
\hline \multirow{2}{*}{ Pair of variables } & \multicolumn{2}{|c|}{ ANOSIM } & \multirow{2}{*}{ SIMPER (Bray-Curtis Dissimilarity) } \\
\hline & $\mathrm{p}$ & $\mathrm{R}$ & \\
\hline \multicolumn{4}{|l|}{ Inter-annual } \\
\hline 2000 vs. 2006 & *** & 0.165 & $\begin{array}{l}\text { H. similis (0); S. grubii }(0) ; H \text {. australis }(0) ; A \text {. isabellei }(0) \text {; } \\
\text { P. tricuspis (0); K. schubartii }(6) ; N \text {. fluviatilis }(6)\end{array}$ \\
\hline Seasons 2000 & *** & 0.776 & \\
\hline SM vs. AT & *** & 0.882 & L. kinbergii (SM); S. tehuelchus (SM); M. kinbergi (SM) \\
\hline SM vs. WT & *** & 0.818 & H. similis (WT); S. tehuelchus (SM); L. kinbergii (SM) \\
\hline SM vs. SP & *** & 0.906 & H. similis (SP); A. isabellei (SM); S. grubii (SM) \\
\hline AT vs. WT & *** & 0.718 & H. similis (WT); C. capitata (AT); N. fluviatilis (WT) \\
\hline AT vs. SP & *** & 0.959 & S. grubii (AT); H. similis (SP); C. capitata (AT) \\
\hline WT vs. SP & *** & 0.457 & S. grubii (WT); A. isabellei (WT); K. schubartii (SP) \\
\hline Seasons 2006 & *** & 0.237 & \\
\hline SM vs. AT & ** & 0.229 & H. australis (SM); K. schubartii (SM); N. fluviatilis (SM) \\
\hline SM vs. WT & ** & 0.263 & H. australis (SM); A. isabellei (WT); K. schubartii (SM) \\
\hline SM vs. SP & *** & 0.299 & H. similis (SP); H. australis (SM); K. schubartii (SP) \\
\hline AT vs. WT & ns & 0.132 & \\
\hline AT vs. SP & ** & 0.377 & H. similis (SP); N. fluviatilis (SP); T. plebeius (SP) \\
\hline WT vs. SP & * & 0.150 & T. plebeius (SP); N. fluviatilis (SP); K. schubartii (SP) \\
\hline
\end{tabular}


(Florida) but these were locally evidenced and had a short-time duration (Lewis et al., 2001). In the same way, even after a reduction of $65 \%$ in the species richness and of $75 \%$ in benthic abundance, sedimentary and benthic recovery were registered six months after the end of dredging in the Harbour of Ceuta, N Africa (Guerra-García et al., 2003). Despite of this capacity of recovery, it is impossible to affirm that the studied macrobenthic assemblages were not significantly impacted in time because the after-dredging periods were beyond the scope of the present work.

In estuarine environments, macrobenthic communities generally are characterized by low diversity with high abundances of a few estuarine species (Day et al., 1989; Attrill et al., 1996), in addition to the opportunistic fauna observed due to organic enrichment from sewage and industrial discharges or salinity stress (Pearson \& Rosenberg, 1978). Therefore, the extent of recovery (or re-adjustment; see McCauley et al., 1977) is limited since any developing community will still be controlled by those physico-chemical disturbances inherent to these habitats.

Recolonization processes can vary on spatialtemporal different scales (Zajac et al., 1998; Hsieh \& Hsu, 1999), being therefore affected by hydrodynamics (Norkko et al., 2001), food availability (Snelgrove et al., 1996), chemical inhibition (Davis et al., 1991), recruitment (Olafsson et al., 1994), temporal fluctuations in the population (Zajac \& Whitlatch, 1982) and species' life histories (Shull, 1997). Another process may rise by formation of hummocks, a sedimentary pattern of undredged material that is commonly found after the passage of suction dredges (McCauley et al., 1977; Grave \& Whitaker, 1999), as those used in the dredging operations analyzed here. This sedimentary feature presents high biological significance in the repopulation process due to residual alive organisms on the hummock itself or immigration of individuals from undisturbed areas to dredged ones (McCauley et al., 1977; Maurer et al., 1981). Recolonization by larval establishment could also have been occurred (Lu \& Wu, 2000) but at a slower rate given the large area affected (Hall et al., 1994; Guerra-García \& García-Gómez, 2006) and the seasonal availability of recruits (Zajac \& Whitlatch, 1982), especially in both winter seasons when the dredging operations started.

Due to the temporal scale of sampling carried out in the present work, it is possible that among benthic surveys the dominant species have recolonized the dredged areas, especially $H$. australis, given the gastropod species high displacement capacity using the superficial water tension (Chomenko \& Schäfer, 1984) and high resilience after disturbances either in adult (Lana, 1986; Netto \& Lana, 1994) or in the planctonic larval stage (Branco et al., 2007). These characteristics allow this species to occupy areas periodically disturbed in which the low density of competitors is a benefit due to the ample spatial/trophic niches (Grassle \& Sanders, 1973; López-Jamar \& Mejuto, 1988; Bemvenuti et al., 1992; van Dalfsen et al., 2000). The similarity found may also have been influenced by the abundant presence of $H$. similis and $N$. fluviatilis, polychaete species which present high resilience after physic disturbances (Bemvenuti, 1997a), in a pattern commonly registered for opportunistic polychaetes like the spionidae Pseudomalacoceros tridentata (Guerra-García et al., 2003) or the capitellid Capitella capitata (Newell et al ., 1998), among others.

Salinity values, and their significant variations, were found here as the main abiotic variable able to structures the macrobenthic assemblages within and between the years, controlling the patters of temporal distribution for both estuarine and marine species inside this subtropical brackish environment, in which the infralittoral macrobenthic fauna responded to distinct settings: the year 2000 with periods from high to extremely low salinity and otherwise the maintenance of brackish waters throughout 2006.

Extremely low values of salinity were registered for the Patos Lagoon estuarine region due to influence of the strong 1997/1998 ENSO phenomenon (Garcia et al., 2001) and, as a consequence, just one year of regular brackish water (1999) may have influenced both macrobenthic density and diversity along the year 2000 . Marine species registered during the summer and autumn seasons inside the estuary, like the polychaete worms S. grubii, P. tricuspis and Marphysa kinbergi, were found in higher densities that decreased over time and presented a small body size, being predominantly juveniles (pers. obs.). That initial elevated salinity may also have influenced in the densities of marine species like the bivalve Solen tehuelchus and the gastropod $A$. isabellei inside the estuary, favoring the maintenance of estuarine species like $H$. similis and $H$. australis in high densities.

Low salinity and/or its variability are known to be responsible for a consistently low number of species occurring in estuarine waters when compared to adjacent environments (Giménez et al., 2005). Density reductions or even absence of marine species inside the estuarine region from winter to spring 2000 were associated to the lower salinity and almost limnetic conditions registered along these seasons. This situation was probably also responsible for reductions in the $H$. australis densities along this period, an escape reaction commonly related to this gastropod species facing salinity disturbances (Chomenko \& Schäfer, 1984). Macrobenthic mortality or activity inhibition can occur when this freshwater condition persists for a long time, resulting in a limited reproductive capacity and 
consequent recruitment failure as observed at shallow areas within this subtropical estuarine region (Colling et al., 2007).

On the other hand, a brackish environment was associated to that registered macrobenthic density, diversity and faunal composition along the year 2006. Estuarine salinity was influenced by low rainfall events from summer 2004 to spring 2006, when was registered a long period of drought in the Patos Lagoon drainage basin, marked by reduced pluviometric means and consequent estuarine salinization (Capítoli et al., 2007). The maintenance of salty waters in the main channel region, in addition to elevated temperatures during summer and then again in spring, may have both favored the recruitments that result in high densities of estuarine species like $H$. australis, $H$. similis and $N$. fluviatilis. Moreover, this brackish water conditions may also have favored the input and survival of marine mollusks ( $A$. isabellei and Pholas campechiensis) and polychaete worms (Cirrophorus americanus, P. tricuspis and $S$. grubii) inside the estuarine region, raising its benthic diversity.

The significant differences registered so far by the present study were probably just a natural variation of the macrobenthic organisms through time, since evidenced alterations in both density and diversity were related to seasonal and/or inter-annual dynamics of the macrobenthic fauna that inhabit this subtropical estuarine region, affecting them almost equal to (or more than) dredging operations (Currie \& Parry, 1996; Dauvin et al., 2006). Besides this natural role, man-induced activities like dredging operations need to be constantly monitored since nowadays are being executed another type of dredging within this deep infralittoral area, a deepening dredging, in which $16000 \mathrm{~m}^{3} \mathrm{~h}^{-1}$ of sediment are uninterruptedly removed in order to increase the main channel depth to $18 \mathrm{~m}$ (SUPRG, pers. comm.).

Great salinity variations or its reduction near to freshwater conditions are able to reduce estuarine density and modify the species composition, affecting negatively the marine species as well. Conversely, the maintenance of saltier waters inside the estuary for a long period can adjust the estuarine macrobenthic assemblages or replace them to marine ones, increasing the diversity of this subtropical estuarine environment manly by marine mollusks and polychaete worms.

\section{ACKNOWLEDGEMENTS}

To Nilton Araújo de Abreu for his valuable field effort; to people in the field work and to the financial support from SUPRG (Superintendência do Porto do Rio Grande).

\section{REFERENCES}

Asmus, M. 1997. Coastal Plain and Patos Lagoon. In: Seeliger, U.; Odebrecht, C. \& Castello, J.P. (eds.) Subtropical Convergence Marine Ecosystem: The Coast and Sea in the Southwestern Atlantic. Springer Verlag, Heidelberg, New York. 09-12pp.

Attrill, M.J. 2002. A testable linear model for diversity trends in estuaries. J. Anim. Ecol. 71: 262-269.

Attrill, M.J.; Ramsay, P.M.; Thomas, R.M. \& Trett, M.W. 1996. An estuarine biodiversity hot-spot. J. Mar. Biol. Ass. U. K. 76(1): 161-175.

Barnes, R.S.K. 1980. Coastal Lagoons: The Natural History of a Neglected Habitat. Cambridge University Press, Cambridge, 106p.

Bemvenuti, C.E. 1997a. Benthic Invertebrates. In: Seeliger, U.; Odebrecht, C. \& Castello, J.P. (eds.) Subtropical Convergence Marine Ecosystem: The Coast and Sea in the Southwestern Atlantic. Springer Verlag, Heidelberg, New York. 43-46pp.

Bemvenuti, C.E. 1997b. Unvegetated Intertidal Flats and Subtidal Bottoms. In: Seeliger, U.; Odebrecht, C. \& Castello, J.P. (eds.) Subtropical Convergence Marine Ecosystem: The Coast and Sea in the Southwestern Atlantic. Springer Verlag, Heidelberg, New York. 7882pp.

Bemvenuti, C.E. \& Netto, S.A. 1998. Distribution and seasonal patterns of the sublittoral benthic macrofauna of Patos Lagoon (South Brazil). Rev. Bras. Biol. 58(2): 211-221.

Bemvenuti, C.E.; Cattaneo, S.A. \& Netto, S.A. 1992. Características estruturais da macrofauna bentônica em dois pontos da região estuarial da Lagoa dos Patos, RS, Brasil. Atlântica. 14: 5-28.

Bemvenuti, C.E.; Rosa-Filho, J.S. \& Elliot, M. 2003. Changes in soft-bottom macrobenthic assemblages after a sulphuric acid spill in the Rio Grande harbor (RS, Brazil). Braz. J. Biol. 63(1): 183-194.

Bemvenuti, C.E.; Angonesi, L.G. \& Gandra, M.S. 2005. Effects of dredging operations on soft bottom macrofauna in a harbor in the Patos Lagoon estuarine region of southern Brazil. Braz. J. Biol. 65(4): 573-581.

Blanchet, H.; de Montaudouin, X.; Chardy, P. \& Bachelet, G. 2005. Structuring factors and recent changes in subtidal macrozoobenthic communities of a coastal lagoon, Arcachon Bay (France). Est. Coast. Shelf Sci. 64(4): 561-576.

Branco, C.W.C.; Kozlowsky-Suzuki, B. \& Esteves, F.A. 2007. Environmental changes and zooplankton temporal and spatial variation in a disturbed Brazilian coastal lagoon. Braz. J. Biol. 67(2): 251-262.

Calliari, L.J. 1997. Environment and Biota of the Patos Lagoon Estuary. Geologial Setting. In: Seeliger, U.; Odebrecht, C. \& Castello, J.P. (eds.) Subtropical 
Convergence Marine Ecosystem: The Coast and Sea in the Southwestern Atlantic. Springer Verlag, Heidelberg, New York. 13-18pp.

Calliari, L.J.; Winterwerp, J.C.; Fernandes, E.; Cuchiara, D.; Vinzon, S.B.; Sperle, M. \& Holland, K.T. 2009. Fine grain sediment transport and deposition in the Patos Lagoon - Cassino beach sedimentary system. Cont. Shelf Res. 29: 515-529.

Capítoli, R.R., 1997. Continental Shelf Benthos. In: Seeliger, U.; Odebrecht, C. \& Castello, J.P. (eds.) Subtropical Convergence Marine Ecosystem: The Coast and Sea in the Southwestern Atlantic. Springer Verlag, Heidelberg, New York. 117-120pp.

Capítoli, R.R. \& Bemvenuti, C.E. 2004. Distribuição batimétrica e variação da diversidade dos macroinvertebrados bentônicos da plataforma continental e talude superior no extremo sul do Brasil. Atlântica. 26: 27-43.

Capítoli, R.R.; Bemvenuti, C.E. \& Gianuca, N.M. 1978. Estudos de ecologia bentônica na região estuarial da Lagoa dos Patos. I. Comunidades bentônicas. Atlântica. 3: 5-21.

Capítoli, R.R.; Colling, L.A. \& Bemvenuti, C.E. 2007. Cenários de distribuição do Mexilhão Dourado Limnoperna fortunei (MOLLUSCA - BIVALVIA) sob distintas condições de salinidade no complexo lagunar Patos - Mirim, RS - Brasil. Atlântica. 30(1): 35-44.

Chomenko, L.A. \& Schäfer, A. 1984. Interpretação biogeográfica da distribuição do gênero Littoridina (Hydrobiidae) nas lagoas costeiras do Rio Grande do Sul, Brasil. Amazoniana. 9(1): 127-146.

Clarke, K.R. \& Gorley, R.N. 2006. PRIMER v6: User Manual/Tutorial. PRIMER-E Ltd., Plymouth, 192p.

Clarke, K.R. \& Warwick, R.M. 2001. Changes in Marine Communities: An Approach to Statistical Analysis and Interpretation. PRIMER-E Ltd., Plymouth, 234p.

Closs, D. 1962. Foraminíferos e Tecamoebas na Lagoa dos Patos. Bol. Esc. Geol. Porto Alegre, Sér. Biol. 11: 1-130.

Colling, L.A.; Bemvenuti, C.E. \& Gandra, M.S. 2007. Seasonal variability on the structure of sublittoral macrozoobenthic association in the Patos Lagoon estuary, southern Brazil. Iheringia, Sér. Zool. 97(3): 1-6.

Cortelezzi, A.; Capítulo, A.R.; Boccardi, L. \& Arocena, R. 2007. Benthic assemblages of a temperate estuarine system in South America: transition from a freshwater to an estuarine zone. J. Mar. Sys. 68: 569-580.

Costa, C.S.B.; Seeliger, U. \& Kinas, P.G. 1988. The effect of wind velocity and direction on the salinity regime in the Patos Lagoon estuary. Ciênc. Cult. 40: 909-912.
Currie, D.R. \& Parry, G.D. 1996. Effects of scallop dredging on a soft sediment community: a largescale experimental study. Mar. Ecol. Prog. Ser. 134: 131-150.

Dauvin, J.C.; Desroy, N.; Janson, A.L.; Vallet, C. \& Duhamel, S. 2006. Recent changes in estuarine benthic and suprabenthic communities resulting from the development of harbour infrastructure. Mar. Poll. Bull. 53: 80-90.

Dauvin, J.C.; Alizier, S.; Vallet, C. \& Ruellet, T. 2010. Does the Port 2000 harbour construction have an effect on the Seine estuary suprabenthic community? Est. Coast. Shelf Sci. 86(1): 42-50.

Davis, A.R.; Butler, A.J. \& van Altena, I. 1991. Settlement behaviour of ascidian larvae: preliminary evidence for inhibition by sponge allelochemicals. Mar. Ecol. Prog. Ser. 72: 117-123.

Day Jr., J.W.; Hall, C.A.S.; Kemp, W.M. \& YáñezArancibia, A. 1989. The estuarine bottom and benthic subsystem. In: Estuarine Ecology. John Wiley and Sons Inc., New York. 338-376pp.

Elliott, M. \& McLusky, D.S. 2002. The need for definitions in understanding estuaries. Est. Coast. Shelf Sci. 55: 815-827.

Elliot, M. \& Quintino, V. 2007. The Estuarine Quality Paradox, Environmental Homeostasis and the difficulty of detecting anthropogenic stress in naturally stressed areas. Mar. Poll. Bull. 54: 640645.

Engler, R.; Saunders, L. \& Wright, T. 1991. Environmental effects of aquatical disposal of dredged material. Environ. Prof. 13: 317-325.

Garcia, C.A.E. 1997. Physical Oceanography. In: Seeliger, U.; Odebrecht, C. \& Castello, J.P. (eds.) Subtropical Convergence Marine Ecosystem: The Coast and Sea in the Southwestern Atlantic. Springer Verlag, Heidelberg, New York. 94-96pp.

Garcia, A.M.; Vieira, J.P. \& Winemiller, K.O. 2001. Dynamics of the shallow-water fish assemblage of the Patos Lagoon estuary (Brazil) during cold and warm ENSO episodes. J. Fish Biol. 59: 1218-1238.

Gianuca, N.M. 1997. Benthic Beach Invertebrates. In: Seeliger, U.; Odebrecht, C. \& Castello, J.P. (eds.) Subtropical Convergence Marine Ecosystem: The Coast and Sea in the Southwestern Atlantic. Springer Verlag, Heidelberg, New York. 114-117pp.

Giménez, L.; Borthagaray, A.I.; Rodríguez, M.; Brazeiro, A. \& Dimitriadis, C. 2005. Scale-dependent patterns of macrofaunal distribution in soft-sediment intertidal habitats along a large-scale estuarine gradient. Helgol. Mar. Res. 59: 224-236.

Grassle, J.S. \& Sanders, H.L. 1973. Life histories and the role of disturbance. Deep-Sea Res. 20(7): 643659. 
Grave, S. \& Whitaker, A. 1999. Benthic community readjustment following dredging of a muddy-maerl matrix. Mar. Poll. Bull. 38(2): 102-108.

Grimm, A.M.; Ferraz, S.E.T. \& Gomes, J. 1998. Precipitation anomalies in Southern Brazil associated with El Niño and La Niña events. J. Climate. 11(10): 2863-2880.

Guerra-García, J.M. \& García-Gómez, J.C. 2006. Recolonization of defaunated sediments: fine versus gross sand and dredging versus experimental trays. Est. Coast. Shelf Sci. 68: 328-342.

Guerra-García, J.M.; Corzo, J. \& García-Gómez, J.C. 2003. Short-term benthic recolonization after dredging in the Harbour of Ceuta, North Africa. Mar. Ecol. 24(3): 217-229.

Hall, S.J.; Raffaelli, D. \& Thrush, S.F. 1994. Patchiness and disturbance in shallow water benthic assemblages. In: Giller, P.S.; Hildrew, A.G. \& Raffaelli, D.G. (eds.) Aquatic Ecology: Scale, Pattern and Process. Blackwell Scientific Publications, London. 333-375pp.

Hartmann, C. \& Harkot, P.F.C. 1990. Influência do canal São Gonçalo no aporte de sedimento para o estuário da laguna dos Patos - RS. Rev. Bras. Geoc. 20: 1-4.

Holland, A.F.; Shaughnessy, A.T. \& Hiegel, M.H. 1987. Long-term variation in mesohaline Chesapeake Bay macrobenthos: spatial and temporal patterns. Estuaries. 10: 227-245.

Hsieh, H.L. \& Hsu, C.F. 1999. Differential recruitment of annelids onto tidal elevations in an estuarine mud flat. Mar. Ecol. Prog. Ser. 177: 93-102.

Kennish, M.J. 1992. Ecology of estuaries:Anthropogenic effects. CRC, Boca Raton, 494p.

Kjerfve, B. 1986. Comparative oceanography of coastal lagoons. In: Wolfe, D. A. (ed.) Estuarine variability. Academic Press, New York. 63-81pp.

Krusche, N.; Saraiva, J.M.B. \& Reboita, M.S. 2003. Normais climatológicas provisórias de 1991 a 2000 para Rio Grande, RS. Editora FURG, Rio Grande, 84p.

Lana, P.C. 1986. Macrofauna bêntica de fundos sublitorais não consolidados da Baía de Paranaguá (Paraná). Nerítica. 1(3): 78-89.

Lewis, M.A.; Weber, D.E.; Stanley, R.S., \& Moore, J.C. 2001. Dredging impact on an urbanized Florida bayou: effects on benthos and algal-periphyton. Environ. Poll. 115: 161-171.

López-Jamar, E. \& Mejuto, J. 1988. Infaunal benthic recolonization after dredging operations in La Coruña Bay, NW Spain. Cah. Biol. Mar. 29(1): 37-49.

Lu, L. \& Wu, R.S.S. 2000. An experimental study on recolonization and succession of marine macrobenthos in defaunated sediment. Mar. Biol. 136: 291-302.
Mannino, A. \& Montagna, P.A. 1997. Small-scale spatial variation in macrobenthic community structure. Estuaries. 20: 159-173.

Marques, J.C.; Maranhão, P. \& Pardal, M.A. 1993. Human impact assessment on the subtidal macrobenthic community structure in the Mondego Estuary (Western Portugal). Est. Coast. Shelf Sci. 37: 403-419.

Maurer, D.; Keck, R.T.; Tinsman, J.C. \& Leathen, W.A. 1981. Vertical migration and mortality of benthos in dredged material: Part 1 - Mollusca. Mar. Environ. Res. 4: 299-319.

McCauley, J.E.; Parr, R.A. \& Hancock, D.R. 1977. Benthic infauna and maintenance dredging: a case study. Water Res. 11: 233-242.

McLusky, D.S. \& Elliott, M. 2004. The Estuarine Ecosystem: Ecology, threats and management. Oxford University Press, Oxford, 216p.

Möller, O.O., 1996. Hydridynamique de la Lagune dos Patos $\left(30^{\circ} \mathrm{S}\right.$, Brésil). Mesures et modélisation. Ph.D. thesis. Bordeaux University, France. 204p.

Netto, S.A. \& Lana, P.C. 1994. Effects of sediment disturbance on the structure of benthic fauna in a subtropical tidal creek of southeastern Brazil. Mar. Ecol. Prog. Ser. 106: 239-247.

Newell, R.C.; Seiderer, L.J. \& Hitchcock, D.R. 1998. The impact of dredging works in coastal waters: a review of the sensitivity to disturbance and subsequent recovery of biological resources on the sea bed. Oceanogr. Mar. Biol. Ann. Rev. 36: 127178.

Nienchesky, L.F.H. \& Baumgarten, M.G.Z. 1997. Environmental Chemistry. In: Seeliger, U.; Odebrecht, C. \& Castello, J.P. (eds.) Subtropical Convergence Marine Ecosystem: The Coast and Sea in the Southwestern Atlantic. Springer Verlag, Heidelberg, New York. 20-23pp.

Norkko, A.; Cummings, V.J.; Thrush, S.F.; Hewitt, J.E. \& Hume, T. 2001. Local dispersal of juvenile bivalves: implications for sandflat ecology. Mar. Ecol. Prog. Ser. 212: 131-144.

Olafsson, E.B.; Peterson, C.H. \& Ambrose, W.G. 1994. Does recruitment limitation structure populations and communities of macro-invertebrates in marine soft sediments: the relative significance of pre and post settlement processes. Oceanogr. Mar. Biol. Ann. Rev. 32: 65-109.

Pearson, T.H. \& Rosenberg, R. 1978. Macrobenthic succession in relation to organic enrichment and pollution of the marine environment. Oceanogr. Mar. Biol. Ann. Rev. 16: 229-311.

Quigley, M.P. \& Hall, J.A. 1999. Recovery of macrobenthic communities after maintenance dredging in the Blyth Estuary, north-east England. Aq. Cons. Mar. Freshw. Ecosyst. 9(1): 63-73. 
Schlacher, T.A. \& Wooldridge, T.H. 1996. Axial zonation patterns of subtidal macrozoobenthos in the Gantoos Estuary, South Africa. Estuaries. 19: 680-696.

Seeliger, U. \& Kjerfve, B. 2001. Coastal Marine Ecosystems of Latin America. Springer-Verlag, Heidelberg, New York, 360p.

Shull, D.H. 1997. Mechanisms of infaunal polychaete dispersal and colonization in an intertidal sandflat. J. Mar. Res. 55: 153-179.

Skilleter, G.A.; Pryor, A.; Miller, S. \& Cameron, B. 2006. Detecting the effects of physical disturbance on benthic assemblages in a subtropical estuary: A Beyond $\mathrm{BACl}$ approach. J. Exp. Mar. Biol. Ecol. 338:271-287.

Snelgrove, P.V.R.; Grassle, J.F. \& Petrecca, R.F. 1996. Experimental evidence for aging food patches as a factor contributing to high macrofauna density. Limnol. Oceanogr. 41(4): 605-614.

Stirling, G. \& Wilsey, B. 2001. Empirical relationships between species richness, evenness, and proportional diversity. Am. Nat. 158 (3): 286-299.

Suguio, K. 1973. Introdução à sedimentologia. EDUSP, São Paulo, 317p.

van Dalfsen, J.A.; Essink, K.; Madsen, H.T.; Birklund, J.; Romero, J. \& Manzanera, M. 2000. Differential response of macrozoobenthos to marine sand extraction in the North Sea and the Western Mediterranean. ICES J. Mar. Sci. 57: 1439-1445.
Vaz, A.C.; Möller, O.O. \& Almeida, T.L. 2006. Análise quantitativa da descarga dos rios afluentes da Lagoa dos Patos. Atlântica. 28(1): 13-23.

Warwick, R.M.; Goss-Custard, J.D.; Kirby, R.; George, C.L.; Pope, N.D. \& Rowden, A.A. 1991. Static and dynamic environmental factors determining the community structure of estuarine macrobenthos in SW Britain: why is the Severn estuary different? J. App. Ecol. 28: 1004-1026.

Ysebaert, T. \& Herman, P.M.J. 2002. Spatial and temporal variation in benthic macrofauna and relationships with environmental variables in an estuarine, intertidal soft-sediment environment. Mar. Ecol. Prog. Ser. 244: 105-124.

Zajac, R.N. \& Whitlatch, R.B. 1982. Responses of estuarine infauna to disturbance. I. Spatial and temporal variation of initial recolonization. Mar. Ecol. Prog. Ser. 10: 1-14.

Zajac, R.N.; Whitlatch, R.B. \& Thrush, S.F. 1998. Recolonization and succession in soft-sediment infaunal communities: the spatial scale of controlling factors. Hydrobiologia 375/376: 227-240.

Zar, J.H. 1984. Biostatistical analysis. Prentice Hall, New Jersey, 718p. 